\title{
"We are prisoners, not inmates": prison letters as liminal counter-carceral spaces
}

\author{
Marco Nocente \\ Dipartimento di Sociologia e Ricerca Sociale, Università degli Studi di Milano-Bicocca, Milan, Italy \\ Correspondence: Marco Nocente (m.nocente1@campus.unimib.it)
}

Received: 19 May 2020 - Revised: 11 May 2021 - Accepted: 28 May 2021 - Published: 1 July 2021

\begin{abstract}
The question of porousness and liminality of prison has been the subject of a huge amount of research. This article focuses on the relationships, communications, and narratives that occur behind prison walls. It examines letter writing in relation to the construction of a bridge that connects the opacity of the inside with the outside, creating a counter-carceral liminal space. The article investigates the encounter between the outside, represented in OLGa (the political collective in which I participate), and the inside (the prisoners) through the process of letter writing. The article further draws upon my own positionality through an engaged discussion on the limitations of scholar activism and the problem of speaking for others.
\end{abstract}

\section{Introduction}

In the literature, there is no shortage of analysis of collections of prison letters. Their content has been used for their value as testimony (Alarid, 2000). There are also other contributions in which letters are used to describe carceral spaces, such as the testimonies of women imprisoned in Spain and Brazil (Padovani, 2013). In this article, I treat prison letters as a "space of betweenness" that narrates and communicates to the outside world what happens behind prison walls. I draw upon a specific empirical experience of letters collection by OLGa (è Ora di Liberarsi dalle Galere) ${ }^{1}$, a small Milan-based collective that serves as a megaphone for the voices of prisoners who oppose the carceral logic and its establishment as a "total institution" (Goffman, 1968). I consider the letters published in these booklets to be a "liminal space", because I consider the exercise of writing in prison to be a "spatial act" (Shabazz, 2014:582) and a form of communication that occurs within and through prison walls. This work is part of a wider research project. Rather than probe the contents of the letters, what follows aims to provide a valuable method of contextualising prison letters and the role of the researcher.

\footnotetext{
${ }^{1}$ Issues of privacy prevent any disclosure of the origins and further details of the collective. See http://www.autprol.org/olga/ (last access: 16 February 2021).
}

In recent years, carceral geography has introduced innovative thinking that reframes the classic concept of "prison" through the notion of the "carceral space" (Moran et al., 2017) to describe prison institutions and other forms of legal and non-legal detention and the carceral logic inherent in the wider society. Carceral geographers reconnect society in its "carceral entirety" (Baudrillard, 1983:9) and consider prison to be "less total, more liminal, less delimited, more porous" (Armstrong and Jefferson, 2017:258). On the one hand, by observing the "carceral" or "carceral archipelago" (Foucault, 1976), we can observe the spread of prison disciplinary techniques throughout society (Moran et al., 2017:3). On the other, the study of carceral spaces views prison as a privileged observation point of the complex dynamics that structure the social order and power relations within our society (Vianello, 2018:832) and as a laboratory of political theories (De Vito, 2014) where practices are produced and tested (Gill et al., 2016:185). Prison in this perspective can be studied through the lens of carceral geography treated not only as the "apotheosis of carceral power" but also as part of a carceral continuum (Hamlin and Speer, 2018:800).

From this perspective, I will develop the notion of prison letters and the archive of booklets in which they are contained as a liminal counter-carceral space: liminal because they are the outcome of the encounter between the inside (prisoners) and the outside (OLGa collective) and counter-carceral 
because they demonstrate that "authoritative control is not totalising", and possibilities remain to create connections through the walls (Russel and Carlton, 2020:308). Letters can act as tools to break down the walls that conceal the "spatial practice of containment, surveillance, and isolation that the geography of prison engenders" (Shabazz, 2014:582). They also overcome the conceptual distinction that can often lead to a binary dichotomy between "inside" and "outside", which is roundly criticised by Baer and Ravneberg (2008) and Moran (2013). Indeed, letters provide a bridge to the outside that conveys a narrative mediated, on the one hand, by the different backgrounds, conduct and counter-conduct, and relationships that prisoners establish and, on the other, by the governmentality of prison management (Conlon, 2013; Foucault, 2007).

Prison is a form of "frontier architecture" (Weizman, 2007:1), created not only to keep people in but also to keep people out. For this reason, the management carefully controls the circulation and the passage of letters and other objects across the walls (Gill et al., 2016), especially when this could challenge the prison order. There is therefore a general interest in keeping its space opaque. The narrative that emerges in this environment tells how "“prisoners' acute relationship with punishment through containment, surveillance and discipline in turn produces knowledge of the workings of carceral power" (Shabazz, 2014:584). For this reason, prison administrations fear the breakdown of their controlled isolation and that the prison's unseen areas will be revealed as a consequence.

In this paper, I will discuss the methodological and ethical challenges of researching prison letters, as collected by the OLGa Collective's archive, through a narrative approach. The narrative approach is here understood as a description of the experience of prisoners by connecting sites and contents of these letters as a collective counter-narrative of unacceptable stories of prison management. After giving insight into the work of the OLGa Collective, its archive, and the types of letters it contains, I will first problematise the institutional environment of prison spaces that shape prisoners' subjectivities and their letters in turn and then develop from this a discussion of the issues of reflexivity and positionality that a narrative approach to prisoners' letters must consider, spanning between activism and academia and the quest of "speaking for others".

\section{The OLGa booklets}

The prison letters that will be presented were sent to a collective that supports prisoners' struggles, providing a megaphone for prisoners' voices. They were digitised and published online by the prisoners themselves in a monthly book- let (March 2006-November 2020). ${ }^{2}$ Since 2006, these booklets have been collected in the Milan collective's archive.

In my research, I have analysed 139 booklets and a total of 1024 letters (March 2006-November 2019) sent from 102 Italian prisons, 1 psychiatric hospital, 2 identification and expulsion centres (CIE), 1 US prison, 18 prisons in other parts of Europe, and 10 prisoners under house arrest. Prisons and other forms of institutions outside Italy were considered when their writers described past experiences in the Italian prison system. The booklets are generally made up of two parts: the first includes a report of events concerning the struggle inside and outside prisons and a chronology of world and national reports from counter-information journals. The second contains prison letters. The two parts are merged by editorial choice. For these reasons, the letters are not removed from their context. The booklets should be considered a preliminary framework since they reflect the method used by the editors to bridge the gap between inside and outside.

OLGa was established to create awareness outside of what goes on inside in order to sustain, unite and strengthen support for the battle against prison. As the collective states

Convinced that prison is an institution functional to the maintenance of an unfair and oppressive social order, our struggle is not to embellish it but to get rid of it. Regarding it as an instrument of isolation and annihilation for thousands of prisoners, we believe it is important to act now to support the struggles as they arise and end the destructive isolation by the state. ${ }^{3}$

OLGa's mission is similar to that of the "Prison Information Group" (GIP $)^{4}$ in that it rejects a reformist horizon of action and shares the idea of converging direct testimonies. Like the GIP, the role of the collective is to act as a conduit between the inside and outside for different individual experiences and funnel them into a shared body of knowledge and coordinated action (Foucault, 2001). This work is largely conducted by activists and former prisoners in some cases.

On the backstage of the editorial work there is a series of ethical precautions taken when negotiating the exchange

\footnotetext{
${ }^{2}$ The letters are collected within the 147 booklets available at the following link: http://www.autprol.org/olga/ (last access: 11 March 2021).

${ }^{3}$ Every quotation up to the end of the paragraph, unless otherwise specified, is taken from the introduction of the booklet; link: http://www.autprol.org/olga/ (last access: 19 March 2021).

${ }^{4}$ The "Groupe d'Information sur les Prisons" (GIP) is a political group created by Michel Foucault, Pierre VidalNaquet, and Jean-Marie Domenach in 1971. This group works with prisoners, families, doctors, lawyers, and militants and has produced five investigative booklets on prison conditions: https://viewpointmag.com/2016/02/16/ manifesto-of-the-groupe-dinformation-sur-les-prisons-1971/ (last access: 16 February 2021).
} 
of letters (Gerber, 2006:143). In OLGa's booklets, prisoners are invited to write about their struggles and report on "their daily experience of resistance". Every time OLGa opens correspondence with new prisoners, it specifies the collective's aims and asks them whether or not they wish to publish their letters. Their letters are then read and discussed at a meeting of the collective. The publications are not always the result of a regular exchange of letters between two parties. Some are open letters from those who heard about the booklet in prison, in the manner of a letter to the editor of a newspaper: "I would like to comment on what L.Q.P. from Poggioreale writes. I agree with him, in part". 5 Sometimes we published letters taken from other journals.

Unlike GIP, we did not constrain the prisoners' remarks within a questionnaire format, demanding factual personal accounts (Brich, 2008:30). Contributions always enjoyed complete stylistic freedom. In our experience, when we asked about specific topics, such as the differentiation between prisoners, the reward mechanisms, or the experience of punitive regimes, we found the responses rather stilted due to the difficulty of restricted communication. This stylistic freedom of expression enabled each prisoner to give a unique view since their experience was "filtered by emotional and cognitive understanding and reported in the personal language of each inmate's usage" (Vannier, 2018:8; Dexter, 2006).

Letters varied in length. Some were written by prisoners with little command of the Italian language while others were extremely fluent. Some prisoners were known to the collective, and others were not. Those who wrote had generally heard about the exercise by word of mouth. Some have written often, and others only once. Sometimes, the cost of sending letters became unaffordable in the long term if prisoners were unable to rely on support networks or due to transfers, release, or personal choice: "Due to others here in this section, I've had trouble with OLGa booklets"6 or "I said that I bury the hatchet and I always keep faith with what I say"7. The language of the booklet is exclusively Italian and this has probably limited its spread.

Personal exchanges of letters are not analysed as such but as open letters in order to respect the right of privacy of those who take part in the collective. Some occasionally state their desire to publish and circulate their writing, either specifying their full name or remaining anonymous. In my research, I decided not to identify the writers by name due to the informality of the relationship between the collective and the pris-

\footnotetext{
${ }^{5}$ Booklet 53, December 2010, "Lettera dal carcere di Carinola", M., activist and long-time writer. L.Q.P. (liberi quanto prima) is the acronym by which a prisoner signed his letter and it means "free as soon as possible".

${ }^{6}$ Booklet 130, January 2018, "Lettera dal carcere delle Vallette", C., activist.

${ }^{7}$ Booklet 98, December-January 2015, "Lettera dal carcere di Spoleto", M. long-time writer.
}

oners and the impossibility of requesting clarification from all the writers.

Where agreed, we publish the name and the address of the prisoners so that those who read the booklet can open an exchange of letters, from both inside and outside. A signed letter implies that the prisoners explicitly accept responsibility for their content. In any case, as described by Vannier, the prisoners "chose to correspond with the knowledge that their letters could be read by the prison "censors"' (Vannier, 2018: 11).

\section{Who is sending the letters?}

The geography of the letters depended on the proximity of the collective. Of the 1024 letters received, most came from Lombardy (210), specifically the Milan prisons of Opera (80) and San Vittore (58). The other Italian regions from which most letters arrived were Piedmont (125), Lazio (90), Campania (86), Sardinia (83), and Umbria (79), notably the prisons of Poggioreale (Campania, 38) Velletri (Lazio, 34), and Terni (Umbria, 31). A total of 280 people wrote to us, including 14 from women's sections.

Academics often divide and categorise inmates across the lines of gender, nationality, religious and political orientation, and social condition. Alternatively, they adopt the categories imposed by the management on the basis of the detention regime, such as medium security, maximum security, etc. The letter writers cannot be regarded as representative of the prison population. They are a heterogeneous but selfselecting group whose struggles reflect the framework and the specific intentions of the booklet.

They bear witness to the most severe Italian prison regimes in terms of physical and psychological deprivation. Some are incarcerated in maximum-security prisons. These regimes expose prisoners to limited sociality, sometimes fewer than 10 to 20 people living for many years in a regime whose primary objective is their neutralisation rather than their reeducation (Wacquant, 2013:x). Other prisoners have written to the OLGa from the isolation cells provided for those whose conduct threatens internal security. There are letters from activists, left-wing militants, anarchists, or communists, arrested for both collective or individual political action and common crimes, some of them in maximum security. There are several prisoners who clearly state their political standpoint. For instance, some sign "communist prisoner" or "W anarchy". These letters end with a slogan that leaves little room for interpretation. Some are known by the collective, and others had been reported in national newspapers. Of the 280 prisoners who wrote to OLGa, 87 are such prisoners. Letters from prisoners with clear, although differing, political identities outweigh those from the rest of the population, although other categories of prisoners are included. For example, there are some letters sent by prisoners held in maximum security for organised mafia crimes. In the early years of the booklet, many letters were received 
from people imprisoned on charges related to "Islamic terrorism" and detained in other maximum-security cells, sometimes shared with the above-mentioned "political" prisoners. Other non-Italians are mainly undocumented migrants or migrants arrested for petty crimes related to conditions of poverty. The most common nationalities are Tunisian (16), Moroccan (9), and Algerian (6). Non-Italians number 51 and also include prisoners from Senegal, Egypt, Switzerland, Romania, Colombia, Turkey, Palestine, Spain, Albania, BosniaHerzegovina, France, Brazil, and Iraq. Those Italians not detained for political or organised criminal activities are serving sentences for common crimes. Some are prisoners with psychiatric problems or drug addiction. Some are known nationally or are supported and represented by a network. These include those able to write books or on whose behalf demonstrations in support of their freedom have been staged. Others, despite belonging to a political, religious, formal, or informal group, act alone, often without the support even of their families.

A distinction can be made between "ordinary" inmates and "political" prisoners. Scholars such as Shabazz (2014) have emphasised the concept of the "political progressive" in relation to a specific political prisoner. His category of political progressive includes internationally renowned inmates like Angela Davis or the Soledad brothers, and the same is true of Martin Sostre's letters (Schaich and Hope, 1977). My archive differs in that only a few prisoners are nationally known and includes a group of political and non-political prisoners who oppose prison management and, as a result, bring different critical content to their struggles. A common feature between these narratives and those in the archive is that they respond to what Sykes (1958) called "the pains of imprisonment". In the letters sent to OLGa, the prisoners struggle against this pain and contribute in a similar way to the creation of a different narrative identity running through the booklet. A sketch of a letter received may help define the narrative identity of those who write to OLGa:

I said: "Good evening prisoners, can I come in?" They answered me, saying: "You're right, we are prisoners not inmates. Of course, you can". They took me in, made my bed, and fed me. ${ }^{8}$

In this case, the word "prisoner" (as opposed to "inmate") reveals the intention of a person who feels critical of the ideology behind the treatment or, at least, someone with a critical view of the penal system who seeks solidarity with the prisoners:

There are those who think, day after day and with all the risks they face, about how they can best use the free time on their hands [...] to seek out others like them and no longer depend on the rules of the

\footnotetext{
${ }^{8}$ Booklet 72, August 2012, "Lettere dal carcere di Prato", Alessio, activist.
}

game. I think of all of them and say to myself: "I'll have to do my part, if only as a way to resist and come out with my head held high, in front of the "brothers" of today and tomorrow. ${ }^{9}$

They can all be called prisoners, but I would say more. Elimination and differentiation in the detention of ordinary prisoners are part of a system of which traditional political prisoners are victims (Foucault, 1974). These differentiation strategies involve both categories. A condition that all prisoners have decided to struggle against itself becomes a political action. In fact, even if they must be considered beyond these formal categories, at most as prisoners, it could be a mistake not to emphasise their political contribution, which makes them, from this point of view, political prisoners. In summary, those who have written to OLGa are not just political progressives or merely traditional prisoners facing the pain of imprisonment, but prisoners fighting within a wider political network. They all share a general identity of being against prisons or, at least, a critical attitude that significantly changes in its expression. Some are more confident with regard to institutional and legal actions, and others avoid any contact with institutions and representatives. Then there are those who move from one to another of these poles, depending on their experience. After 27 years of imprisonment, this prisoner says

I don't mind if the prison is decongested, if the prison delivers improvements in the "life" of prisoners, but my thinking, my struggle cannot stop with the achievement of these goals. I don't want a better prison, I don't want the prison as an institution, that's the point. ${ }^{10}$

There is a recurring phrase in the letters of some of the older prisoners that can be summarised in this way: "There are no longer the prisoners of the past". This is a reference to a particular historical period in the early 1980s that continues to this day. Due to a series of incentives to cooperate in exchange for rewards, such as early release, an irreparable rift has been created between prisoners, in some cases throwing the boundaries of the relationship between guards and prisoners into question.

This identity fosters a solidarity among prisoners in opposing this trend of individualisation and lack of mutual trust. The identity that emerges in the booklet shows that prisoners are united against a power that affects everyone. In other words, the damage and effects caused by the experience of prison contribute to the construction of a collective prison identity shared by everybody irrespective of their crimes or political views. The creation of a common identity becomes a response to prison strategies for maintaining control.

\footnotetext{
${ }^{9}$ Booklet 90, March 2014, "Lettera dal carcere di Alessandria. Quello stesso formicolio (That same tingle)". N., activist.

${ }^{10}$ Booklet 58, June 2011, "Lettera dal carcere di Pescara", E.
} 
The identities of the writers are many but they often have similar narratives. As mentioned in several letters, the identity of most is that of "prisoner engaged in struggle":

Not having any cultural background, my education and my culture has been formed by the street and the jail. [...] I don't have any coherent political thought to guide me, only the passion for rebellion, revolt, the rejection of any form of coercion, which drive me to attain individual freedom. [...] my solidarity is unconditionally with all the men and women in chains who, while retaining their dignity, do not trade away their freedom or trample on the freedom of others. I feel no solidarity with those who, despite being in chains, accept and recognise the correctional treatment and do not hesitate to denounce others within the walls of the office of the commander, educator, etc. ${ }^{11}$

The booklet's relative success in creating an exchange between the inside and the outside lies in reinforcing this identity, under threat from the most recent changes in prison logic, spaces, and practices:

It is the prisoners who have changed radically at their core. Solidarity no longer exists and, in exchange for benefits, they are willing to play the game. Confiding in someone has become a risky option and you're forced to keep everything inside. Fortunately, through your booklet, I am glad to discover many fellow prisoners who think like me, and knowing that there are people outside who, in their own small way, can be of help to us, makes me feel better and full of hope. ${ }^{12}$

The booklet succeeds in uniting and transmitting knowledge and experience that can be transferred between the inside and the outside. Sharing knowledge means creating a voice that represents the writer and those close to him or her. It is a dynamic representation that is written repeatedly in the booklets and that unites all those who are critical of the management, a voice that also speaks for those who cannot speak at that moment. It is not a representative voice of the Italian prison population as a whole but reflects many in different prisons who have challenged incarceration. The booklet was also able to respect silence. When I talk of the "empowerment" of an oppressed group, I cannot limit myself only to giving voice (Crang, 2005:231). While it may be virtuous to enable the silenced to speak, disregarding silence would turn a virtue into a vice. Giving voice to prisoners or the content of their narratives means deciding what to make public. It is therefore neither "native and untouched" nor more "authentic" than others but rather a narrative constructed together and complicit with the outside.

\footnotetext{
${ }^{11}$ Booklet 58, June 2011, "Lettera dal carcere di Pescara", E.

${ }^{12}$ Booklet 82, July 2013, "Lettera dal carcere di Opera", A.
}

\section{A narrative approach}

The problem of dealing with the voice of others leads me to reflect on the way in which it is possible to approach the knowledge produced by the booklet. Therefore, in this section I will present the method by which I circumscribe this knowledge, also considering my role as editor and activist.

The method I pursued in my research draws on sociological classics, such as Thomas and Znaniecki (1918) and Wright Mills (1959) on sociological imagination; the more recent narrative approach developed in criminology that contributes to how inmates use discursive resistance strategies in prison (Fleetwood et al., 2019; Vannier, 2018); the discussion in geography about narrative turn in the humanities and social sciences and the emphasis on narrative activity, i.e. how the narrative is constructed and what the different narrative environments are (Prokkola, 2014); insights into personal correspondences, the question of truth in narratives; the historicity of the material and the limits and opportunities given by the specificity of epistolary exchanges in social history (Elliott et al., 2006); the development from critical criminology and geography on the narratives of prisoners (Earle, 2019); and the narratives of political prisoners (Schaich and Hope, 1977; Shabazz, 2014).

As the editor of the booklet, it was common for me to say, on reading a letter, "They write as they speak". Storytelling as an oral medium (Benjamin, 1992:84) bears similarities with prison writing as described by Davies (1990). Like storytelling, prison writings are characterised by "art repeating stories" (Benjamin, 1992:90): writing letters, rewriting space-time and experience, and placing an individual in a collective story. Writing from prison creates a space of atomisation that would otherwise be lived in solitude (Abbot, 1981; Abu-Jamal, 1995). The importance of rewriting has also been "deployed by feminist and postcolonial authors, as a method of reclaiming the experiences of marginalised groups" from their own points of view (March and Palmer, 2018:35). Narratives are small literary truths, they can feed "the sociological imagination in ways that conventional socio-scientific writing is rarely able to do" (Earle, 2019).

This article seeks to underline the importance of narrative that combines OLGa intervention on prison and the "convict" knowledge of prisoners engaged in struggle, a hybrid knowledge that unites "intimate, visceral understanding about the loss of liberty, the meaning of confinement, the power of the state, the force of punishment, finding freedom" (Earle, 2018:15) and narrative that describes the experience of prisoners affected by the power of the prison management. I intend to contribute to an immanent story in opposition to that of power, or of the winner who tells of victory. This archive thereby becomes a collective counter-narrative of unacceptable stories, such as those of blacks in new British prisons (Earle, 2019).

I analysed the archive by reading and rereading the letters, insights, and contextualisation of the booklet. It is a circular 
process, as described by Morgan (2008), an ongoing analysis in which new data emerge "so that both the research procedures and questions can be adjusted in an iterative fashion in response to what is being learned in the field" (Morgan, 2008:246). The justification of this choice is the fact that I found no similar work at the local or national level on which it could be based (Vannier, 2018:11; Peräkylä, 2005:870). The booklet allows me to conceptualise the "narrative environments" of the letters (Prokkola, 2014:442), without limiting them to simple textual end products. In addition, the letters are compared with other sources, such as laws and other documentary evidence.

The booklet's narrative environment, the content of the letters, and my reading as a researcher formed a meta-archive. I began working on the original archive made up of the different booklets. On the one hand, I extracted quantitative information by sorting the material by the geography of the different prisons, the regimes, the origins of the prisoners, and the types of letters (when specified). On the other, I reorganised the original archive with the narrative environment of the booklet and the content of the letters. Whenever possible, I connected events that united the different, sometimes divergent, points of view of the prisoners discussing the same subject but from a different prison, block, or cell or simply from a different perception of reality. In this circular process, I defined different thematic areas, building up a new archive of letters, contextual insights, and academic references extrapolated from the material. In this way, I was able to make use of the original archive ordered chronologically, a small database of quantitative information, and another archive divided into thematic areas. The analysis intersected with this differentiated source in parallel with discussion with the OLGa Collective and the prisoners with whom I have exchanged letters, or with other prisoners I had the pleasure to meet after their release. Meaning is co-created and co-constructed (Crotty, 1998), eroding the distance between "me", as a researcher and activist, and the prisoners. The research reflects my determination to expand these counter-narratives into new areas, such as the academic circuit. It was conceived at a time when I felt that this material could become relevant, in fact I was part of the collective even before I started the research. While this may limit my ability to understand the narratives, I think it is, for me, the only ethically respectable way, given the writer's own position, in order to give full importance to the subjective realities of the letter writers. I brought general collective knowledge and a reflexive guide to the analysis of the letters. A guide acquired through the history and experience of past struggles described within the booklet and reiterated in each personal discussion with prisoners and activists.

This guiding has been used to trace the past in order to understand the present (Story, 2016). It is genealogical knowledge that makes it possible to understand the prisoners' writings, especially those in which a poor command of language is combined with unspoken considerations, that is, writers who can sometimes seem incomprehensible or events known by all that were major turning points in prisoners' narratives. This guide has also helped me to question analysis that I once took for granted and make the interpretative decisions that I did. Furthermore, this guide helped fill the silences with an explanation of why someone had disappeared from the booklet; it serves as a commentary on delicate issues that have been made public; it recognises when silences are the most eloquent way to communicate in sensitive moments. In brief, it guided me in more fully emphasising the voice and the silence described in the last section.

\section{Spanning activism and academia: reflexivity and positionality}

Some scholars assert that speaking on behalf of others "is arrogant, vain, immoral and politically illegitimate". Moreover, the "indignity of speaking for others" (Foucault and Deleuze, 1978) often increases and strengthens the oppression of the group for which one speaks (Alcoff, 1994:287). For this reason, some scholars believe that researchers should speak only for the groups of which they are members, even if the delimitation of their boundaries is variable and porous and the delimitation of identity is arbitrary (Alcoff, 1994:4). In this paragraph, I will conceptualise two main issues that concern my positionality and my reflexivity in relation to prison letters and the narrative environment from which they come.

Firstly, my positionality is derived from my participation in the collective. Writing in the 1960s, the sociologist Becker (1967) believed that a critical approach should address the question "Where do we stand?" (Hudson, 2001). From this world view, on the one hand, I want to stress the link between activist practice and academic studies, between the material produced by the OLGa Collective and my reflection and analysis. On the other, since I am an activist and work in the university sector that speaks for those whose voices are silenced, I would under no circumstances renounce my "political responsibility to speak out against oppression", precisely because this responsibility is based on my own privilege (Alcoff, 1994:288). Starting from the question of the indefinable limit of belonging to a group, I believe it possible to produce valuable work even under these conditions.

I have never been incarcerated as a prisoner and, for this reason, I am able to consider the question as an activist and scholar and not as a former prisoner. Nevertheless, my own specific position allows me to speak about prison through my personal experience in constructing a bridge between the inside and the outside in order to support the struggle of others. This is acknowledged by both the editors of the booklet and the prisoners with whom I engaged.

Participation in the collective and the editorial group also demands a brief personal statement. I entered a prison as part of my work as a university tutor. After two and a half years with prisoners enrolled at the university, I was suspended 
by management for two main reasons: my closeness and friendship with the prisoners and my refusal to inform the prison educator about the individual behaviour of the prisoners through daily reports on our activity. My refusal and its consequences inculcated radical critical thought within me regarding the institution of the prison. This prompted me to become an abolitionist and a militant member of a libertarian collective.

Right from the start, both as a volunteer and an activist, I saw the paradoxical tension that lay in building a bridge between prisoners and society. Such activity can be portrayed as a threat to the social order but it was also the most spontaneous and honest path open to me. This contradiction was also fundamental for the development of the booklet. The prison censorship office defined the booklets as follows: "they are not of the 'permitted kind', since they do not enter the commercial circuit outside the prison"13 and "the contents incite rebellion against the State and, more specifically, against prison facilities"14. For years, attempts by me and OLGa to send the booklet to prisoners were rejected and censored by many prisons on the grounds that security requirements exclude these types of connections between prison and society and between different prisons.

Secondly, "claims of reflexivity can provide a platform for claiming an authenticity or realness of experience which is spurious" (Phillips, 2012:54). Participation in the collective gave me the opportunity to highlight certain thematic areas that constitute a general milieu that has been built up over the years through the booklet. This condition helped me to deal with the risk of interpreting the meanings of the letters. A risk inherent in the different perceptions that exist between "the analyst" and the disordered group with respect to the shape that the research seeks to take (Waddington, 1991:228).

This article attempts to problematise my role within the encounter between OLGa and the prisoners within the booklet. The criticisms made by Brich (2008) of the GIP are particularly relevant in questioning my reflexivity. Although I put a high value on the voice of the prisoners, and although this voice may be given greater rein than in a questionnaire, as in GIP's case, it cannot be said that I am acting as a megaphone for the prisoners. That is the work of the collective. While it is also important to free the prisoners' voices of restrictions, there is a risk that speaking on their behalf obscures their voices. My aim in researching the world of prisons is to describe the specific encounter between the outside (the collective) and the inside (the prisoners). It is not merely the collection of testimonies; I am acting here as a witness to this encounter. It is precisely my proximity to the environment that allows me to build up a "situated knowledge" on

\footnotetext{
${ }^{13}$ Booklet 114, June 2016, "Lettera dal carcere di Agrigento", D. activist, isolation cell.

${ }^{14}$ Booklet 129, December 2017, "Lettera dal carcere di Uta", M. activist, isolation cell.
}

prisons and prisoners that could not be attained from a safe distance (Haraway, 1988).

However, the series of subjective choices on the part of the researcher in directing a certain flow of discourse, interpreting the material with personal nuances, and choosing how to present it must all be made clear (McLafferty, 1995:437). This is certainly a constraint on the research, for which I try to compensate by justifying the roles I have played and by pursuing a hybrid work that crosses different discourses.

\section{Conclusion}

In this article, I presented a specific archive of letters that raises several issues regarding space, narratives, power, identity, and liminality within the debate among carceral geographers.

Among them, I stressed the importance of a specific archive of letters, the narrative approach to analyse them, and my positionality and reflexivity. I presented a collective narrative - the narrative of prisoners affected by prison power and an outside group - that exists "betwixt and between" prisons (Moran, 2013:16). I described the composition of an archive composed of letters from prisoners who are outspoken in their opposition to prison management, even if there are differences between them. To this end, I have primarily presented how the material was produced by exploring the nature and significance of these published prison letters (Jones, 2006:176).

I propose a second academic life for the prison letters collected by OLGa, from my unique position as a scholar activist (Gilmore, 2007). There is no distinction between this role and the environment in which the letters were collected, since the researcher is both the publisher of the booklet and part of the collective. In spite of the physical barrier between me and the prisoners, this work is drawn directly from the political activity and interaction between the collective and the prisoners. This positionality, on the one hand, can help the observed environment to be understood and, on the other, requires necessary precautions regarding the question of "speaking for others". Moreover, it avoids an approach limited to textual end products and fosters the development of knowledge composed of the experiences of all the subjects included in the research. This approach analyses the specific encounter that takes material form in the booklet and seeks a perspective that gives a more eclectic view of the phenomena.

In short, the booklet is a counter-carceral liminal space where OLGa intervention on prison and prisoners' narratives of resistance is merged. Letters from prison show how a network of solidarity can shed light on opaque spaces. The article underlines the power of connection, creating bridges and spaces of resistance that are produced through the correspondence between prisoners and between prison and society. The letters produce two kinds of spaces within the 
booklet, a space that was concealed from society that could be revealed through their testimony and counter-carceral spaces, the space for resistance that can transcend the walls (Shabazz, 2014). The prisoners' narratives, crystallised in the booklets, "transform, repurpose and reimagine" the prison space (Shabazz, 2014) and reinforce the construction of a common identity against prison.

Finally, the archive is in Italian, and it is freely accessible and available for further analysis with text analysis software or based on new themes and interpretations, starting from the different subjects who have given evidence of their prison experience. In this article, I have shown the potential to construct knowledge and realities that are different from the dominant one (Prokkola, 2014:445). Each of these contributions represents prison narratives that differ from the many published works, data, and knowledge production that reflect the rhetoric of prison management and are limited by "security levels, state or federal systems, or regional jurisdictions" (Ross et al., 2011:160). Starting from the geographic specificity of the archive, this work seeks to contribute to the construction of narratives aimed at "disavowing" the "hegemonic and universalising idea of "the Prison" (Armstrong and Jefferson, 2017:238) and build a bridge between prison and society in order to cast light on the opaque.

Data availability. The letters are collected within the 147 booklets available at the following link: http://www.autprol.org/olga/ (last access: 29 June 2021.) (Collettivo OLGa, 2021).

Competing interests. The author declares that there is no conflict of interest.

Disclaimer. Publisher's note: Copernicus Publications remains neutral with regard to jurisdictional claims in published maps and institutional affiliations.

Acknowledgements. The author would like to thank all the reviewers and colleagues who helped him: in chronological order, Marina Richter and Anna Schliehe; Elena Dell'Agnese; the two anonymous reviewers; colleagues from the University of Essex $\mathrm{PhD}$ seminar organised by Yasemin Soysal, in particular Passent Moussa; and the editor of the journal, Benedikt Korf.

Review statement. This paper was edited by Benedikt Korf and reviewed by two anonymous referees.

\section{References}

Abbot, J. H.: In the Belly of the Beast: Letters from Prison, Random House, New York, https://doi.org/10.1176/ps.33.10.856, 1981.

Abu-Jamal, M.: Live From Death Row, Addison-Wesley Pub. Co., Reading, Massachusetts, 1995.

Alarid, L. F.: Sexual assault and coercion among incarcerated women prisoners: Excerpts from prison letters, Prison J., 80, 391-406, https://doi.org/10.4135/9781452229454.n10, 2000.

Alcoff, L.: The Problem of Speaking for Others, in: Feminist Nightmares: Women at Odds: Feminism and the Problem of Sisterhood, edited by: Weisser, S. O. and Fleischner, J., New York University Press, New York, 285-309, 1994.

Armstrong, S. and Jefferson, A.: Disavowing 'the' prison, in: Carceral Spatiality: Dialogues Between Geography and Criminology, edited by: Moran, D., and Schliehe, A., Palgrave Macmillan, London, 237-269, https://doi.org/10.1057/978-1137-56057-5, 2017.

Baer, L. D. and Ravneberg, B.: The outside and inside in Norwegian and English prisons, Geograf. Ann. B, 90, 205-216, https://doi.org/10.1111/j.1468-0467.2008.00287.x, 2008.

Baudrillard, J.: Simulations, translated by: Beitchman, P., Foss, P., and Patton, P., Semiotext(e), Columbia University, New York City, New York, 1983.

Becker, H.: Whose side are we on?, Social Problems, 14, 239-247, https://doi.org/10.2307/799147, 1967.

Benjamin, W.: Illuminations, translated by: Zohn, H., Fontana Press, London, 1992.

Brich, C.: The Groupe d'Information sur les Prisons: The voice of prisoners? Or Foucault's?, Foucault Studies, 5, 26-47, https://doi.org/10.22439/fs.v0i5.1408, 2008.

Collettivo OLGa (è Ora di Liberarsi dalle GAlere): Opuscoli, available at: http://www.autprol.org/olga/, last access: 29 June 2021.

Conlon, D.: Hungering for freedom: Asylum seekers' hunger strikes - rethinking resistance as counter-conduct, in: Carceral Spaces: Mobility and Agency in Imprisonment and Migrant Detention, edited by: Moran, D., Gill, N., and Conlon, D., Ashgate, Farnham, 133-148, 2013.

Crang, M.: Qualitative methods: there is nothing outside the text?, Prog. Human Geogr., 29, 225-233, 2005.

Crotty, M.: The Foundations of Social Research: Meaning and Perspective in the Research Process, SAGE, Newcastle upon Tyne, 1998.

Davies, I.: Writers in Prison, Basil Blackwell, Oxford, 1990.

De Vito, C. G.: Camosci e girachiavi: Storia del carcere in Italia, Gius. Laterza \& Figli Spa, Laterza Editori, Bari, 2014.

Dexter, L. A.: Elite and Specialized Interviewing, ECPR classics, Colchester, 2006.

Earle, R.: Convict criminology in England: developments and dilemmas, Brit. J. Criminol., 58, 1499-1516, https://doi.org/10.1093/bjc/azy016, 2018.

Earle, R.: Narrative Convictions, Conviction narratives: The Prospect of Convict Criminology, in: The Emerald Handbook of Narrative Criminology, edited by: Fleetwood, J., Presser, L., Sandberg, S., and Ugelvick, T., Emerald Publishing Limited, Bingley, 63-83, https://doi.org/10.1108/978-1-78769-005920191009, 2019. 
Elliott, B. S., Gerber, D. A., and Sinke, S. M.: Letters across borders. The Epistolary Practices of International Migrants, Palgrave Macmillan, New York, 2006.

Fleetwood, J., Presser, L., Sandberg, S., and Ugelvick, T.: Introduction, in: The Emerald Handbook of Narrative Criminology, edited by: Fleetwood, J., Presser, L., Sandberg, S., and Ugelvick, Emerald Publishing Limited, Bingley, 1-26, 2019.

Foucault, M.: Michel Foucault on Attica: An Interview, in: A proposito della prigione d'Attica, Telos, 19, 154-161, 1974.

Foucault, M.: Sorvegliare e Punire, translated by: Tarchetti, A., Einaudi, Torino, 1976.

Foucault, M.: Dits et écrits, Gallimard, "Quarto", in: vol. 1, Paris, 2001

Foucault, M.: Territory, Population: Lectures at the Collège de France, edited by: Senellart, M., translated by: Burchell, G., Palgrave, New York, 2007.

Foucault, M. and Deleuze, G.: Intellettuali e potere, in: Microfisica del potere: interventi politici, edited by: Fontana, A. and Pasquino, P., translated by: Procacci, G. and Pasquino, P., Einaudi, Torino, 1978

Gerber, D. A.: Epistolary masquerades: Acts of deceiving and withholding in immigrant letters. in: Letters across Borders, edited by: Elliott, B. S., Gerber, D. A., and Sinke, S. M., Palgrave Macmillan, New York, 141-157, https://doi.org/10.1057/9780230601079_8, 2006.

Gill, N., Conlon, D., Moran, D., and Burridge, A.: Carceral circuitry: New directions in carceral geography, Prog. Human Geogr., 42, 183-204, https://doi.org/10.1177/0309132516671823, 2016.

Gilmore, R. W.: Golden Gulag: Surplus, Crisis and Opposition in Globalizing California, University of California, Berkeley, 2007.

Goffman, E.: Asylums: Essays on the social situation of mental patients and other inmates, AldineTransaction, Piscataway, NJ, 1968.

Hamlin, M. and Speer, J.: The politics of conceptualizing the carceral: A commentary on Moran et al. (2017), Prog. Human Geogr., 42, 799-802, 2018.

Haraway, D.: Situated Knowledges: The Science Question in Feminism and the Privilege of Partial Perspective, Feminist Stud., 14, 575-599, https://doi.org/10.2307/3178066, 1988.

Hudson, B.: Critical Reflection as Research Methodology, in: Doing Criminological Research, SAGE Publications, London, 175192, https://doi.org/10.4135/9780857024404, 2001.

Jones, W. D.: "Going into Print": Published Immigrant Letters, Webs of Personal Relations, and the Emergence of the Welsh Public Sphere, in: Letters across Borders, edited by: Elliott, B. S., Gerber, D. A., and Sinke, S. M., Palgrave Macmillan, New York, 175-199, https://doi.org/10.1057/9780230601079_10, 2006.

March, E. and Palmer, B.: "Unique incarceration events": The Politics of Power in Margaret Atwood's Prison Narratives, Margaret Atwood Stud., 12, 11-50, 2018.

McLafferty, S.: Counting for women, Profess. Geogr., 47, 436-442, 1995.

Moran, D.: Between outside and inside? Prison visiting rooms as liminal carceral spaces, GeoJ., 78, 339-351, https://doi.org/10.1007/s10708-011-9442-6, 2013.

Moran, D., Turner, J., and Schliehe, A.: Conceptualizing the Carceral in Carceral geography, Prog. Human Geogr., 42, 666686, https://doi.org/10.1177/0309132517710352, 2017.
Morgan, D.: Emergent design, in: The Sage encyclopedia of qualitative research methods, edited by: Given, L. M., Sage, Thousand Oaks, CA, 246-249, 2008.

Padovani, N. C.: Confounding Borders and Walls: Documents, letters and the governance of relationships in São Paulo and Barcelona prisons, Vibrant: Virt. Brazil. Anthropol., 10, 340 376, https://doi.org/10.1590/s1809-43412013000200011, 2013.

Peräkylä, A.: Analyzing talk and text, in: The SAGE Handbook of Qualitative Research, edited by: Denzin, N. K. and Lincoln, Y. S., SAGE, Los Angeles, CA, 869-886, 2005.

Phillips, C.: The multicultural prison: Ethnicity, masculinity and social relations among prisoners, Oxford University Press, Oxford, UK, https://doi.org/10.1093/acprof:oso/9780199697229.001.0001, 2012.

Prokkola, E.: Using Narrativity as Methodological Tool, ACME J., 13, 442-449, 2014.

Ross, J., Richards, S., Newbold, G., Lenza, M., and Grigsby, R.: Convict criminology, Critical Criminology 2011, Springer, Belmont, CA, 160-171, https://doi.org/10.4324/9780203864326.ch12, 2011.

Russell, E. K. and Carlton, B.: Counter-carceral acoustemologies: Sound, permeability and feminist protest at the prison boundary, Theor. Criminol., 24, 296-313, https://doi.org/10.1177/1362480618769862, 2020.

Schaich, W. and Hope, D. S.: The Prison Letters of Martin Sostre, Documents of resistance, J. Black Stud., 7, 281-300, https://doi.org/10.1177/002193477700700303, 1977.

Shabazz, R.: Walls Turned Sideways are Bridges: Carceral Scripts and the Transformation of the Prison Space, ACME J., 13, 581594, 2014.

Story, B.: The prison inside: a genealogy of solitary confinement as counter-resistance, in: Historical Geographies of Prisons: Unlocking the Usable Carceral Past, edited by: Morin, K. M. and Moran, D., Routledge, Abingdon, 34-50, https://doi.org/10.4324/9781315724997-3, 2016.

Sykes, G. M.: The Society of Captives: A Study of a Maximum Security Prison, Princeton University Press, Princeton, 1958.

Thomas, W. and Znaniecki, S.: The polish peasant in Europe and America: Primary-group organization, Badger, Boston, 1918.

Vannier, M.: The power of the pen: Prisoners' letters to explore extreme imprisonment, Criminol. Crim. Just., 20, 249-267, https://doi.org/10.1177/1748895818818872, 2018.

Vianello, F.: Com'è; possibile l'ordine sociale? Il contributo dell' etnografia carceraria allo studio del potere e delle resistenze, in: Rassegna Italiana di Sociologia, Fascicolo 4, 2018, Mulino, Bologna, 831-837, 2018.

Wacquant, L.: Forward: Probing the meta-prison, in: The globalization of supermax prisons, edited by: Ross, J. I., Rutgers University Press, New Brunswick, NJ, 2013.

Waddington, P. A. J.: The Strong Arm of the Law: Armed and Public Order Policing, Clarendon, Oxford, 1991.

Weizman, E.: Hollow Land, Verso, London, 2007.

Wright Mills, C.: The Sociological Imagination, Oxford University Press, Oxford, 1959. 